\title{
Innovations in Public and Non-profit Sector Organizations in China
}

\author{
G. Zhiyong Lan $^{1,2}$ and Joseph Galaskiewicz ${ }^{3}$ \\ ${ }^{1}$ Arizona State University, USA, ${ }^{2}$ Renmin University, China, and ${ }^{3}$ University of Arizona, USA
}

ABSTRACT This article provides background information on public and non-profit sector innovation in the past thirty years in the West as well as in China. We summarized and commented on the articles in this issue, which document cases of public and non-profit sector innovation in China and theorize their significance. These cases tell vivid stories about how Chinese organizations innovate and also point out the importance of the role of government in initiating or constraining these innovations. We find, through the review of these studies, that China's public and non-profit sector organization innovation experiences carry some important messages about the unique features of China's public and non-profit organizations that should not be ignored while studying changes in China.

KEYWORDS collaboration, innovation, non-government organizations, public organizations

\section{INTRODUCTION}

Public and non-profit sector organizations play a critical role in modern life. Together with business organizations, they constitute an organizational network that enables the distribution and exercise of public and private functions that facilitate political, economic, and social development. In the past few decades, the drive for efficiency, effectiveness, and global competitiveness has propelled a global movement of managerial reform and organizational re-invention, which is also evident in China. Business and public organizations alike have raced to get on the bandwagon of change and innovation.

While business organizations have their bottom-line - profit, public, and nonprofit sector organizations are subject to competing claims. Besides typical interpersonal and inter-organizational tensions, such as personnel grievances, labour disputes, and organizational jurisdiction disputes, public and non-profit sector organizations have to worry about many other tensions. These include: economic development vs. environmental protection; rising public interest concerns vs. the call for individual choice; decentralization of power vs. the need for coordinating 
larger tasks of high technology development and global competition; increased social wealth vs. the enduring problems of poverty and crime; shaken public confidence in government and large corporations vs. increased need for direction by leaders in a complex world; uncompetitive compensation vs. the requirement for high-quality public service personnel; organizational uncertainty vs. increased reliance on employee loyalty to public service; high-level national debt vs. increased pressure for public spending on social and environmental programs; democratic demands vs. calls for greater efficiency and effectiveness; special interests vs. the general public interest; national homogeneity vs. cultural diversity claims; need for cooperation and tensions among ethnic groups and between genders; nationalism vs. internationalism; and promotion for free international markets vs. new tariffs to protect domestic industries. The length of this list, which is by no means exhaustive, underscores a powerful message that the challenges faced by public and non-profit organization leaders are truly arduous.

As a fast growing transitional economy, China has also been experiencing rapid social change. Its public and non-profit organizations face challenges that are both typical of their international counterparts and unique. The challenges are typical because China is part of the international community that shares many of the contemporary problems of other countries. The challenges are unique because China is in the process of transforming from a traditional totalitarian command economy into an open market economy. Its public institutions and non-profit organizations have to find ways to work with, and promote, the ever expanding market economy, and to integrate China's economy with that of the international community in spite of their institutional legacies from the traditional top-down command economy. The tactics these public and non-profit organizations use for meeting their challenges, the way they innovate and change, and the mentality they have for their institutional reforms could all have significant bearings on China's future directions of change. Over the years since China opened up to the outside world, many changes have occurred. However, many questions remain. Have all these changes been made in the right way? What innovations have occurred? What lessons can be learned? How can positive experiences be transferred to other localities and the pitfalls avoided? How will China eventually develop and change because of these innovations?

In this issue, we aim at identifying, documenting, analysing, and theorizing cases of successful innovations in public and non-profit sector organizations in China. It complements the earlier MOR special issue on 'Creativity, Innovation, and Entrepreneurship in China'. In our context, public sector organizations refer to central governmental agencies, state, county, municipal, township governmental units, and quasi-government enterprises, and non-profit organizations include educational and research institutions, professional associations and societies, foundations, long standing community groups, citizen groups, religious groups, and international non-government organizations (NGOs). Innovations are changes 
made either in the administrative process, in service delivery, in institutional design, or leadership and organizational culture. Given the broad range of issues involved and the challenges public and non-profit organizations face, there is no way we could do justice to address them all in one issue of a journal. However, the few articles we have gathered here, though limited in scope, may allow us a glimpse of what has been happening in China. According to a Chinese saying, you may see a leopard by peeping at a spot. Hopefully, through these few articles or spots of the leopard, we get a sense of how China's public and non-profit organizations make their changes and the unique challenges they face.

In the following, we first discuss background information of public sector reform in the West as well in China, and then discuss non-profit sector reform trends for both. Afterward, we review each of the papers published in this issue with the hope of identifying the unique characteristics and commonalities of public and nonprofit sector innovation efforts in China. Finally, we discuss the limitations of this issue and raised expectations for further research in these areas.

\section{INNOVATIONS IN THE PUBLIC SEGTOR}

Public sector innovation has dominated the reform agenda of many countries in the past thirty years (Hood, 1991; Lan, 1999; Lan \& Rosenbloom, 1992; Merget, 2003; Werlin, 2003). Government reform, decentralization of power, work process reengineering, citizen participation, decision network, new public management, new public service, and collaboration governance have all been catchwords driving changes in the public sector (Bozeman, 2002; Goldsmith \& Eggers, 2004; Kettl, 2000; Pei, 2002; Proust, 1997; Schick, 1998). It should be noted that in a conventional sense, sector classification is based on property rights. The government sector is supported by taxes; hence it is considered public sector. Privately owned businesses are supported by business proceeds and therefore, considered to be the private sector. The non-profit (or the non-government) sector lies in between, often times using private means to fulfill public functions and being treated as quasi-public sector organizations (Bozeman, 1987; Perry \& Rainey, 1988). Public sector reform and innovation focus on making changes in government institutions, processes, rules and regulations, service mentalities, and operational techniques for the sake of improving efficiency, effectiveness, and citizen satisfaction. In the West, many government organizations sought to borrow methods from private and non-profit organizations (Savas, 1987). More recently, ideas of new public management, network governance, collaborative governance have been called for.

In China, public sector reform has taken a slightly different route. Relaxation of government control, introduction of the market, re-organization of government agencies as well as reorganizing government owned businesses (State owned businesses), changing operational procedures, increasing accountability, or improving 
service delivery have become the norm. In many places, citizen participation is encouraged. Typical changes in the public sector include reshuffling of organizational units, decentralization of power, re-engineering of government processes, strengthening performance measurements, and allowing for more citizen participation. The unanswered question is whether these changes and innovations will lead to fundamental institutional and social change (Kettl, 2000; Lan \& Rosenbloom, 1992; Neshkova \& Kostadinova, 2012; Savas, 1987).

Indeed, over the years since 1978, China has made many rounds of administrative reforms, including major efforts in 1982, 1988, 1993, 1998, 2003, 2005, and 2008. It could be said that the reforms between 1982 and 2003 were mostly aimed at reducing the size of the government while the reforms after 2003 had to do with the changing of government functions to allow for more market-driven forces and for better integration of government functions with agencies (Wang, $\mathrm{Wu}, \&$ Wang, 2008). Nonetheless, many problems endure. The transformation of governmental functions to allow for market space is not yet accomplished, public service and social management is still inadequate, administrative structures are still problematic, and administrative accountability is still not properly enforced. Therefore, change of government functions, rule of law, transparency in government affairs, and anti-corruption are still quoted as major reform targets by China's leaders ( $\mathrm{Li}$, 2012). It is a pity that we were unable to secure contributions directly addressing the issues of government agency reform in this particular issue. However, we have obtained articles discussing governmental adoption of new ways for developing the local economy (land banking system diffusion), scholars' participation in project management and implementation, use of collaborative methods to battle HIV/ AIDS, and corporatism in China. Of all the published articles in this issue, a unifying reference is that all the changes are somewhat related, driven, guided, or constrained by the government, underscoring a powerful message - the reform of government agencies is essential for China's progress.

\section{INNOVATIONS IN THE NON-PROFIT SECTOR}

Non-profit organization innovation is another theme for this issue, and because this may be less familiar to readers we go into a little more detail. On the one extreme, these organizations may not be incorporated or even recognized by governments in any formal sense. On the other, they may have very close ties to the government, either through direct funding, reporting requirements, or even shared personnel. Some are heavily supported by commercial sales, have paid employees, and redistribute very little to the poor or disadvantaged, while others are pure charities supported by donations and serve the disadvantaged. In practice, most are blended forms, being similar to business firms and government agencies in their funding, governance, and administration. To make any statement about innovations in the non-profit sector is difficult because the range of organizations is so broad and 
there is a great variety of activity that goes on under the banner of non-profit or non-government. Three trends in the innovation of non-profit organizations management are easily discernible from the global scene. They are: (i) blurring of the boundaries between public and private firms; (ii) the role of the internet in the advocacy of social causes; and (iii) the personalized nature of philanthropy.

\section{Blurring of the Boundaries}

The most striking innovation is the blurring of the boundaries across sectors, the purpose being to harness the unique capabilities of the different sectors to address common problems. Two innovations stand out. First, there are cross-sector partnerships and collaborations. Here non-profit organizations co-operate with governments and businesses to pursue a range of goals. Second, new hybrid organizational forms are emerging, which incorporate elements of different sectors within their operations. The social enterprise is perhaps the best known.

With privatization (or outsourcing) government-non-profit relations have intensified, and there is no sign of this abating in the West (Salamon, 2012). Scholars and practitioners debate the impact of these partnerships on service delivery, government accountability, and the autonomy of the organizations receiving government funding (Milward \& Provan, 2000). However, while binding non-profits to the government sector, these partnerships also give them greater access to government and a platform to advocate as insiders on behalf of their clientele or members (Chaves, Stephens, \& Galaskiewicz, 2004; Marwell, 2007; Mosley, 2012). In East Asian countries, ties between the non-profit sector and state are more complex and intense and the autonomy of the non-profit sector is always in question (e.g., see Pekkanen, 2006 and Schwartz \& Pharr, 2003 on Japan and Hsu, 2010, Ma, 2006, and Unger, 2008 on China). In this issue Kojima, Choe, Ohtomo, and Tsujinaka (2012) show that social organizations' autonomy from the state in China is increasing and they play an important role in representing members' interests to the government, yet ties remain strong. Studying ostensibly illegal grassroots NGOs in a Chinese authoritarian state, Spires (2011) argues that the former can exist if they perform important social services and refrain from democratic claims-making (see also Wang, 2012 in this issue), but the state is omnipresent.

Cross-sector collaborations are networks among government, non-profit, and business entities to address a wide range of issues. The former are often driven by public concern, initiated by the funder - sometimes a government or a foundation - and the roles that organizations play can vary, for example, from being fully participatory partners in shared governance structures to playing subordinate roles ceding decision making to a lead organization or a network administrative organization (Provan \& Kenis, 2008). The range of problems that these collaborative efforts address is wide ranging, for example, care for the chronically mental ill 
(Provan \& Milward, 1995), development of bio-technology (Powell \& Owen-Smith, 1998), disaster relief (Simo \& Bies, 2007), and economic development (Ebrahim, 2003) to name a few. Collaborative efforts in China are also evident. In this issue Wang (2012) looks at partnerships aimed to eradicate HIV/AIDS in Yunnan Province; in an earlier MOR issue Dollinger, $\mathrm{Li}$, and Mooney (2010) examined the Beijing Olympics. These studies and others illustrate how the problems with these efforts are considerable, for example, finding effective governance structures, being responsive to the local community, balancing power relationships among partners, and ensuring accountability (see Provan \& Kenis, 2008).

The social enterprise takes blurring to the extreme. Young (2009: 23) says that a 'social enterprise is activity intended to address social goals through the operation of private organizations in the marketplace'. Galaskiewicz and Barringer (2012:52) argue that 'The social enterprise is special, because it incorporates contradictory institutional logics [the business and the charity logics] into its mission and operations'. Some social enterprises simply cross-subsidize charitable activities with earned income, but others weave the logics together in their operations and view themselves as change agents. The social enterprise is now found around the world (see Defourny \& Nyssens, 2012 for how the form looks in Europe; Defourny \& Kim, 2011 examine the form in East Asia). The way that social entrepreneurs blend elements of the non-profit and for-profit varies dramatically and the pattern reflects the local culture and context (Kerlin, 2012), consistent with the social origins approach to understanding cross-cultural variation in non-profit forms (Salamon \& Anheier, 1998). The cultural and political context of these forms also affect the extent to which they are accepted and effective (see, for example, Karnani, 2011; Rangan, Chu, \& Petkoski, 2011). Social enterprises are only now beginning in China. Zhao (2012) describes the phenomenon and its meaning in China, showing how the forms it takes are shaped by both global and local forces and, at the same time, reflect the values of leaders and supporters.

\section{Advocacy in the Internet Era}

Recently there is much discussion about the role that the internet plays in advocacy. Journalists have reported on the role of Twitter and Facebook in the Arab Spring uprising, and most in the U.S. are familiar with the activist website moveon.org. Around the world, flash mobs have rattled government officials as they recognised the potential of social networking, text messaging, and cell phone communication. The same technology that enables flash mobs can enable smart mobs. Earl and Kimport (2011) showed that the web affords not only a method to circulate petitions and disseminate political information but also reduces the costs of creating, organizing, and participating in protest. The results are that the web not only can mobilize thousands, or even millions, of petitioners who can make their views known almost instantly, but also can facilitate more traditional tactics, 
such as getting people to show up at a rally or engaging, in a coordinated way, in disruptive behaviour. The low costs of engaging in web-based advocacy, however, means that almost anyone or any organization can become a political lightning rod. The tight control of the Chinese Government over the internet may reflect its concern over technology's political potential.

Another new development is the participation of international NGOs as insiders in shaping public policies and in formulating solutions in partnerships with governments and businesses. Keck and Sikkink (1998; see also Acosta, 2012) showed how international NGOs can leverage concessions from governments by applying indirect pressure on governments at the international level in alliance with other organizations. For example, in the environmental field, a transnational advocacy group such as Greenpeace will coordinate its efforts with other groups to put both direct and indirect pressures on governments and businesses to change their environmental policies and practices. But international NGOs also are directly involved in deliberations about the content of environmental treaties, for example, both as advocates and experts (Betsill \& Corell, 2008) and have been active organizers of transnational private regulatory systems working in cooperation with governments and businesses on labour and environmental issues (Bartley, 2003, 2007). As Wang (2012) describes in this issue, the Chinese government has been tepid towards international NGOs but does not keep them at arms-length either. It recognizes that they often bring funds and needed expertise.

\section{Personalized Nature of Philanthropy}

An important innovation in philanthropy is that it is becoming highly personal. For instance, more and more giving is driven by 'donor choice' (Barman, 2006, 2007). In workplace giving campaigns in many U.S. cities, fundraisers now let the donor earmark where their gift will go instead of pooling contributions and letting a city-wide body such as the United Way decide where the money will be allocated. A variant on the donor choice model is the 'giving circle'. Here donors do not give as individuals but rather come together with other donors to pool their resources much like investor clubs - so as to support causes of mutual interest (Schweitzer, 2000). Many of these groups are very informal, while others are highly organized (Eikenberry, 2006). The latter are often referred to as venture funds and the donors venture philanthropists (Arrillaga-Andreessen, 2012; Moody, 2008). The social venture funds solicit donations and then investors decide what to fund with the guidance of the fund manager (Hodgkinson, Nelson, \& Sivak, 2002). Giving goes to fewer donees, but the relationship is long term and donors and the fund become personally involved with the organization, perhaps joining the board of directors. The purpose is to help the organization go 'in the right direction' and ensure a measureable social return on the investment, although some look for a material return as well. 
The internet is another innovation that gives donors control over their gifts. Arrillaga-Andreessen (2012) describes how the internet enabled thousands of individual donors to aggregate their resources and channel gifts to various causes. E-philanthropy or online philanthropy, of course, was very effective in mobilizing resources for disaster relief, for example, the hurricane in Haiti, the earthquake in Sichuan, China, and the tsunami in Japan. However, the web has gone way beyond this. For example, the 'Make It Your Own Awards' initiative of the Case Foundation asked ordinary citizens to use their website to tell them what causes they should support. Arrillaga-Andreessen (2012) also describes how text message giving and smart-phone donations have been growing in the last few years. The interactive nature of the internet - people can chat with each other, webcams can give people visuals - can help reduce the distance between the donor and a distant donee and thus the uncertainty often associated with a gift. She describes Kiva.com which enables investors to give small loans to entrepreneurs in developing countries, and provides real-time information on the people one is helping. Another feature of online giving is that donors can connect to one another through social media like Facebook, which then can spawn advocacy groups (Arrillaga-Andreessen, 2012: 61). The significance of online giving is that it is able to aggregate small donations into huge sums that can rival the gifts of foundations and wealthy donors. The internet truly gives 'power to the people'.

While trying to be part of the international reform initiative, China's non-profit organizations face their own institutional challenges. As many know, China's non-profit organizations (NPO) were integrated into the government after the establishment of the People's Republic of China in 1949. Civilian organizations literally disappeared. After 1978, China's landmark reform date, non-profit organizations began to re-emerge but with a low profile. Only in recent years, with rapid economic development and a multiplication of social demands, particularly the push of the Olympic Games and the Sichuan Earthquake, non-profit organizations have grown exponentially (see Kojima et al., 2012, Fig. 1 for data from 1988 to 2009). They have started to play more and more important roles in fulfilling the social services gaps left by the government and business. However, the current NPO registration requirement (they have to get to approval by registering with the Civil Administration Department of the government or be affiliated with an existing governmental agency) and dual management system (both the Civil Administration Department and the governmental unit they are affiliated with) have constrained the development of NPOs. Many newly emerged grassroots NPOs do not have legal status since they do not have a government agency agreeing to be their supervisor. To date, the government has passed relevant laws and regulations relaxing its traditionally tight control over civilian organizations, and NPOs are also joining together to promote the change in government regulations in favour of NPO development. Especially after 2002, the Government has changed its attitude 
towards NPOs from close supervision and control to assisting in growth and development. Since 2008, the Government has started to purchase services from NPOs. While today, talent loss, funding, legal identity, and organizational integrity are often problems bothering China's non-profit organizations, they are nonetheless fast growing and gradually becoming a social force to be reckoned with. Perhaps so-called corporatism is one idea that these non-profit organizations may strive to pursue.

\section{THE PAPERS IN THIS SPECIAL ISSUE}

While the papers in this issue cannot possibly cover all the issues we were hoping to discuss, they nonetheless provide a set of innovative stories about public and non-profit organization changes in China.

Zhang's (2012) paper 'Institutional sources of reform: The diffusion of land banking systems in China' describes the diffusion of a popular local government practice in China - land banking - through which local governments purchase, develop, and resell the developed land for proceeds that are, in turn, used for local development and public service. While this system has proven to be useful for driving local economic development, its diffusion, however, is subject to various institutional constraints, which are so far under-recognized. Through his empirical analyses, Zhang convincingly argues that not only local development needs, but also various institutional forces, such as fiscal and political dependencies upon upper level governments, peer competition, and expert opinion, are working together to shape the trajectory of the reform. In other words, China's government innovations are driven as much from the top as from local needs.

Wang's (2012) paper, 'Yunnan's government-driven multi-sector partnership model', illustrates the issues involved in a multi-sector collaboration to help eradicate the HIV/AIDS epidemic in Yunnan Province in southern China. In her in-depth case study of the collaboration, she contrasts this government-led initiative to initiatives that are led by donors and NGOs in other countries. In China foreign involvement is less. More interestingly, she highlights the importance of government agencies working hand-in-hand with non-government groups ranging from social organizations to informal groups of citizens in order to build effective programs. Thus, even in a state-centric political system like China's, collaboration across sectors is vital. However, Wang makes it clear that government officials took the lead and coordinated the network.

The paper by Wang, Yin, and Zhou (2012), 'The adoption of bottom-up governance in China's homeowner associations', describes how homeowner associations (HOAs) in Beijing reorganized themselves in order to better articulate the interests of their members in light of initiatives by developers to take advantage of them. This paper is based on face-to-face interviews with leaders of 91 
HOAs in Beijing from March 2006 to February 2007. The study shows that about half of the HOAs surveyed adopted some kind of bottom-up governance structure. They did this to elicit grassroots participation to deal with developers when they did not have the political connections with the government to resolve the problem. Leaders' values also had a big impact on the choice of governance structures. The research reflects well on the extant social movement literature and shows how this type of non-governmental organization will empower its membership if there are threats to the community that the government is unwilling to mitigate.

Yang's (2012) article, 'Building a knowledge-driven society: Scholar participation and governance in large public works projects', uses forty-nine cases (thirtytwo from China and seventeen from other countries) to study the impact of scholars' participation. He found that scholars' participation is more effective when the projects are at the grassroots level or there is low political intervention. Scholar's participation is more likely to be successful if five rules of thumb (five principles) are followed (knowledge is uniquely produced, knowledge possession by experts is asymmetric, pilot tests are important, incentives for experts are critical, multiple methods of knowledge application is necessary).

The article by Kojima et al. (2012), "The corporatist system and social organizations in China', focuses on changes in the social organization (SO) sector where gradually these entities are gaining autonomy from the state. Using survey data from 2,858 SOs in 2002-2004, they found that SOs founded in the $21^{\text {st }}$ century tend to be more oriented towards interest representation than those founded in the 1980s or 1990s. They also are more likely to be established from the bottom up, to have fewer party connections, and to be less dependent upon the government for funding. However, the government still has as much input over their personnel matters as SOs founded earlier. Also newer SOs expressed less satisfaction with the government's way of managing the SO system. However, having more autonomy did not correlate strongly with being dissatisfied with the management system. The authors conclude that $\mathrm{SO}$ may be moving away from being appendages to the state government, towards advocacy on behalf of different interests within China.

\section{FUTURE RESEARCH}

The articles in this issue provide a range of innovative stories including using land banking systems to address local government financial difficulties, collaborative governance, citizen participation, the intellectual role in decision making, new mentalities in newly founded non-profit organizations, and corporatism and social organizations in China. However, China's reform and change is a historical event - it is impossible for one collection of articles to do justice in fully covering these stories. 
Future research needs to have more in-depth integration of theory and practice. For example, Kojima et al.'s article brought up the framework of corporatism. Corporatism, also known as corporativism, is a system of economic, political, or social organization that involves association of the people of society into corporate groups, such as agricultural, business, ethnic, labour, military, patronage, or scientific affiliations, on the basis of common interests (Busky, 2000). One of the main types of corporatism is economic tripartism, involving negotiations between business, labour, and state interest groups to establish economic policy. This framework can be very well used to analyze the relationship between the State, the non-government, and the non-profit sector in China. Besides, corporatist types of community and social interaction are common to many ideologies, including: absolutism, capitalism, conservatism, fascism, liberalism, progressivism, reactionism, social democracy, socialism, and syndicalism. Its unique articulations, characteristics, and possible future prospects in the Chinese setting could be a very interesting discussion.

Kojima et al.'s paper is such an effort (2012). It presents an extensive literature review on whether China is moving away from state corporatism to social corporatism or even to civil society (see also Ma, 2006). Drawing on Schmitter (1974), they define state corporatism as the condition where the initiation, control, and accountability of state and non-state corporate entities are all engineered by the government. Societal corporatism has organized entities that have institutionalized ties and connections to the state sector, but leaders are accountable to their membership, and the various interests are autonomous. The state though is still the protector of the common good, and the associations are expected to control their members and defer to the state (Unger \& Chan, 2008: 49). Civil society is characterized by voluntary groups, formed solely by private citizens who both articulate their interests and try to find a sense of collective moral purpose (the 'public good'). This undertaking is autonomous of, and often in opposition to, governments and businesses (Alexander, 2006; Dekker, 2009).

Future research needs to examine the new institutional arrangements that will define the relationship between the government and groups of private citizens. Given the history of China and the tradition of state centric institutions, it is difficult to believe that China will adopt a Western style civil society model where NGOs operate in opposition to the state (Ma, 2006). In fact, NGOs seem quite content to maintain and build alliances with government ( $\mathrm{Hsu}, 2010)$, and there seems to be little discontent with the social organization management system (Kojima et al., 2012). But, still, as the papers in this special issue show (especially Wang et al., 2012), there will be innovations in the ways citizens assume more and more responsibilities for solving society's problems, especially as the interests of businesses come into conflict with those of citizens. We do not know what they will be, and whether they will be unique to the Chinese case. These are fascinating and important topics for future research. 
Another set of issues to follow is how the vast private wealth that Chinese people are accumulating can be tapped to further the common good. With increased concentration of wealth in a small group of people, differences in consumption patterns, and possibly social classes, are starting to emerge. While the rich and the not-so-rich spontaneously opened their hearts and wallets to support the victims of the Sichuan earthquake, scholars of giving and volunteering have found that institutions are needed to structure and motivate contributions so that they meet, on a routine basis, societal needs. For example, Hsu (2008) showed the difficulty of soliciting donations for a Western style Chinese NGO in the postsocialist era. The solutions of Project Hope were to blur the distinction between the state and the organization and to try to build personal relationships between the donor and the poor rural students who were benefiting. As Salamon and Anheier (1998) argued, the innovative ways that a society figures out how to institutionalize philanthropy depends on the culture, the institutions, and the social circumstances in which a society finds itself embedded. However, predicting how philanthropy will evolve in China is almost impossible, given its unique situation. Research is needed.

From the research papers we have, we clearly see that, regardless of the specifics, the authors generally have consensus that in China, government-driven initiatives or institutional constraint have been ubiquitous, showing that within the Chinese system, changes and innovations can hardly happen without a role played by the government. Regrettably, in this issue, we had difficulty finding good articles directly addressing the issues of change and innovation in government agencies. The places where change was most needed, and change was a must, and change has definitely happened, were the least described. For example, innovation includes new perspectives, new ways of thinking, new organizational structure, new processes, new technology and methods, new institutional environments, and new results (organizational outcomes). Many of these interesting topics in the public and non-profit sectors are yet to be explored.

Also, in a fast changing society, population migration, social stability, urbanization, public service delivery equity, education, medical system housing, employment, economic structure upgrading, social welfare, financial system reform, rebuilding social trust, and emergency management are all urgent policy issues waiting to be addressed. Studies describing innovative and sustainable efforts are badly needed.

Since ancient times, China has been a country in which its rulers have tried all they could to maintain a unified nation with a small educated elite. This is still the case in today's China. In what way, or to what extent, this traditional mentality can help further the changes in China remains an interesting question. Future research may have a need to focus on not only innovative changes in organizations, processes, and methods, but innovations in perception, culture, and deep-rooted philosophical cognition. Only when changes 
and innovation occur at a more profound level can changes and innovation be sustained.

\section{NOTES}

We would like to thank David Suarez and Jennifer Mosley for reminding us of some non-profit innovations that we had not thought of.

\section{REFERENCES}

Acosta, R. 2012. Advocacy nctworks through a multidisciplinary lens: Implications for research agendas. Voluntas, 23(1): 156-181.

Alcxander, J. C. 2006. The civil sphere. New York: Oxford University Press.

Arrillaga-Andrcessen, L. 2012. Giving 2.0: Transform your giving and our world. San Francisco, CiA: Jossey-Bass Publishers.

Barman, E. 2006. Contesting communities: The transformation of workplace charity. Stanford, CA: Stanford University Press.

Barman, E. 2007. An institutional approach to donor control: From dyadic ties to a field-level analysis. American Journal of Sociology, 112(5): 1416-1457.

Bartley, T. 2003. Certifying forests and factories: States, social movements, and the rise of privatc regulation in the apparel and forest products fields. Politics and Society, 31(3): 433-464.

Bartley, T. 2007. Institutional emergence in an era of globalization: "The rise of transnational private regulation of labor and environmental condition. American Journal of Sociology, 113(2): 297-351.

Betsill, M. M., \& Corell, E. (Eds.). 2008. NGO diplomacy: The influence of nongovernmental organizations in international environmental negotiations. Cambridge, MA: The MIT Press.

Bozeman, B. 1987. All organizations are public: Bridging public and private organizational theories. Washington DC: Jossey Bass.

Bozeman, B. 2002. Public-value failure: When efficient markets may not do. Public Administration Review, 62(2): 145-161.

Busky, D. F. 2000. Democratic socialism: A global survey. Westport, CT: Greenwood Publishing Group, Inc.

Chaves, M., Stephens, L., \& Galaskiewicz, J. 2004. Does governmental funding suppress nonprofits' political activity? American Sociological Reviewe, 69(2): 292-316.

Defourny, J., \& Kim, S.-Y. 2011 . Emerging models of social enterprise in eastern Asia: A crosscountry analysis. Social Enterprise Joumal, 7(1): 86-111.

Defourny, J., \& Nyssens, M. 2012. Conceptions of social enterprise in Europe: A comparative perspective with the United States. In B. Gidron \& Z. Hasenfeld (Eds.), Social enterprises: An organizational perspective: $71-90$. New York: Pelgrave/Macmillan.

Dekker, P. 2009. Givicness: From civil socicty to civic services? Voluntas, 20(3): 220-238.

Dollinger, M. J., Li, X., \& Mooney, C. H. 2010. Extending the resource-based view to the megaevent: Entrepreneurial rents and innovation. Management and Organization Revieze, $6(2): 195-218$.

Earl, J., \& Kimport, K. 201 1. Digitally enabled social change: Activism in the internet age. Cambridge, MA: The MIT Press.

Ebrahim, A. 2003. NGOs and organizational change: Discourse, reporting, and learning. New York: Cambridge University Press.

Eikenberry, A. M. 2006. Giving circles: Growing grassroots philanthropy. Nonprofit and Voluntary Sector Quarterly, 35(3): 517-532.

Galaskicwicz, J., \& Barringer, S. N. 2012. Social enterprises and social categories. In B. Gidron \& Z. Hasenfeld (Eds.), Social enterprises: An organizational perspective: 47-70. New York: Palgrave/Macmillan.

Goldsmith, S., \& Eggers, W. D. 2004. Goveming by network. Washington, DC: Brookings Institution Press. 
Hodgkinson, V. A., Nelson, K. E., \& Sivak, E. D. Jr. 2002. Individual giving and volunteering. In L. M. Salamon (Ed.), The state of nonprofit America: 387-420. Washington, DG: Brookings Institution Press.

Hood, C. 1991. A public management for all seasons? Public Administration, 69(1): 3-19.

Hsu, C. L. 2008. 'Rehabilitating charity' in China: The case of project hope and the rise of nonprofit organizations. Journal of Civil Society, 4(2): 81-96.

Hsu, C. L. 2010. Beyond civil society: An organizational perspective on state-NGO relations in the People's Republic of China. Joumal of Civil Society, 6(3): 259-277.

Karnani, A. 2011. Microfinance needs regulation. Stanford Social Innovation Revieze, 9(1): $48-53$.

Keck, M. E., \& Sikkink, K. 1998. Activists beyond borders: Advocacy networks in international politics. Ithaca, NY: Cornell University Press.

Kerlin,J. A. 2012. Defining social enterprise across different contexts: A conceptual framework based on institutional factors. In B. Gidron \& Z. Hasenfeld (Eds.), Social enterprises: An organizational perspective: 91-117. New York: Pelgrave/Macmillan.

Kettl, D. F. 2000. The transformation of governance: Globalization, devolution, and the role of government. Public Administration Revieze, 60(6): 488-495.

Kojima, K., Choe, J.-Y., Ohtomo, T., \& Tsujinaka, Y. 2012. The corporate system and social organizations in China. Management and Organization Revieze, 8(3): 609628.

Lan, Z. 1999. The 1998 administrative reform in China: Issues, challenges, and prospects. The Asian Journal of Public Administration, 21(1): 29-54.

Lan, Z., \& Rosenbloom, D. 1992. Public administration in transition. Public Administration Reviere, 52(6): 5-7.

Li, J. 2012. Xinhua news people's net.

Ma, Q. 2006. Non-governmental organizations in contemporary China: Paving the zeay to civil society? New York: Routledge.

Marwell, N. P. 2007. Bargaining for Brooklyn: Community organizations in the entrepreneurial city. Chicago, IL: University of Chicago Press.

Merget, A. E. 2003. Donald C. Stone lecture. Public Administration Review, 63(4): 390-395.

Milward, H. B., \& Provan, K. G. 2000. Governing the hollow state. Joumal of Public Administration Research and Theory, 10(2): 359-379.

Moody, M. 2008. Building a culture: The construction and evolution of venture philanthropy as a new organizational ficld. Nonprofit and Voluntary Sector Quarterly, 37(2): 324-352.

Moslcy, J. E. 2012. Keeping the lights on: How government funding concerns drive the advocacy agendas of nonprofit homeless service providers. Journal of Public Administration Research and Theory, 22(4): 841-866.

Neshkova, M. I., \& Kostadinova, T. 2012. The effectiveness of administrative reform in new democracies. Public Administration Review, 72(3): 324-333.

Pci, M. 2002. China's governing crisis. Foreign Affairs, 81(5): 1-18.

Pckkanen, R. 2006. Japan's dual civil society: Members without advocates. Stanford, CA: Stanford University Press.

Perry, J., \& Rainey, H. 1988. The public-private distinction in organization theory: A critique and rescarch strategy. Academy of Management Revieze, 13(2): 182-201.

Powell, W. W., \& Owen-Smith, J. 1998. Universities as creators and retailers of intellectual property: Life-sciences research and commercial development. In B. A. Weisbrod (Ed.), To profit or not to profit: The commercial transformation of the nonprofit sector: 169-193. New York: Cambridge University Press.

Proust, E. 1997. Implementing the contract state. Australian Joumal of Public Administration, 56(3): 132-134.

Provan, K. G., \& Kenis, P. 2008. Modes of network governance: Structure, management, and effectiveness. Journal of Public Administration Research and Theory, 18(2): 229252.

Provan, K. G., \& Milward, H. B. 1995. A preliminary theory of interorganizational network effectiveness: A comparative study of four community mental health systems. Administrative Science Quarterly, 40(1): 1-33. 
Rangan, V. K., Chu, M., \& Petkoski, D. 2011. Segmenting the base of the pyramid. Harvard Business Revieze, 89(6): 113-117.

Salamon, L. M. 2012. The resilient sector: The future of nonprofit America. In L. Salamon (Ed.), The state of nonprofit America: 3-86. Washington, DC: Brookings Institution F'ress.

Salamon, L. M., \& Anheier, H. K. 1998. Social origins of civil society: Explaining the nonprofit sector cross-nationally. Voluntas, 9(3): 213-247.

Savas, E. S. 1987. Privatization: The key to better government. Chatham, NJ: Chatham House Publishers.

Schick, A. 1998. Why most developing countries should not try New Zealand's reforms. The World Bank Research Observer, 13(1): 123-131.

Schmitter, P. C. 1974. Still the century of corporatism? The Revieze of Politics, 36(1): $85-131$.

Schwartz, F. J., \& Pharr, S. J. (Eds.). 2003. The state of civil society in Japan. New York: Cambridge University Press.

Schwcitzer, C. 2000. Building on new foundations. Association Management, (Oct): 28-39.

Simo, G., \& Bies, A. 2007. The role of nonprofits in disaster response: An expanded model of cross-scctor collaboration. Public Administration Revieze, 67(1): 125-142.

Spircs, A. J. 2011 . Contingent symbiosis and civil society in an authoritarian state: Understanding the survival of China's grassroots NGOs. American Joumal of Sociology, 117(1): 1-45.

Unger, J. (Ed.). 2008. Associations and the Chinese state: Contested spaces. Armonk, NY: M. E. Sharpe.

Unger, J., \& Chan, A. 2008. Associations in a bind: The emergence of political corporatism. In J. Unger (Ed.), Associations and the Chinese state: Contested spaces: 48-68. Armonk, NY: M. E. Sharpe.

Wang, F., Yin, H., \& Zhou, Z. 2012. The adoption of bottom-up governance in China's homeowner associations. Management and Organization Revieze, 8(3): 559-583.

Wang, M. 2012. Managing HIV/AIDS: Yunnan's government-driven, multi-sector partnership model. Management and Organization Review, 8(3): 535-557.

Wang, Y., Wu, W., \& Wang, X. 2008. China's 30 year administrative reform. People's Net-Theory Channel.

Werlin, H. H. 2003. Poor nations, rich nations: A theory of governance. Public Administration Reviez, 63(3): 329-339.

Yang, L. 2012. Building a knowledge-driven society: Scholar participation and governance in large public works projects. Management and Organization Revieze, 8(3): 585-607.

Young, D. R. 2009. Alternative perspectives on social enterprise. In J. J. Cordes \& E. Steuerle (Eds.), Nonprofits and business: 21-46. Washington, DC: The Urban Institute Press.

Zhang, Y. 2012. Institutional sources of reform: The diffusion of land banking systems in China. Management and Organization Revieze, 8(3): 507-533.

Zhao, M. 2012. The social enterprise emerges in China. Stanford Social Innovation Revieze, 10(2): $30-35$. 
G. Zhiyong Lan (lanzhiyong2005@163.com) is Professor of Public Administration at Renmin University and Arizona State University. He obtained his Ph.D. from the Maxwell School of Public Affairs and Citizenship. His research focuses on administrative reform, government innovation, e-government, and government and business relations. He has published extensively in both English and Chinese.

Joseph Galaskiewicz (galaskie@email.arizona.edu) is Professor of Sociology at the University of Arizona. Previously he was Professor of Sociology in the College of Liberal Arts and Professor of Strategic Management \& Organization in the Carlson School of Management at the University of Minnesota. He has published extensively in the areas of non-profit sector management, networks, and the urban community.

Manuscript received: July 16, 2012

Final version accepted: August 23, 2012

Accepted by:

Anne S. Tsui 